\title{
The Increasing of Peasants' Income Farmers in Amoron'i Mania Region by Ameliorating the Production System of Rabbit
}

\author{
Randriamandratonirina Nicolas Joseph*, Razaivaovololoniaina Helinoro Diamondra, \\ Falinirina Marie Virginie, Razafintsalama Voahiraniaina, Rakotozandriny Jean de Neupomuscene \\ Higher Institute Technology D'antananarivo, Department of Animal Husbandry, College of Agricultural Sciences, \\ University of Antananarivo, Madagascar
}

Copyright (C) 2015 by authors, all rights reserved. Authors agree that this article remains permanently open access under the terms of the Creative Commons Attribution License 4.0 International License

\begin{abstract}
Madagascar is a developing country on agricultural issue. The population growth brings about poverty problems due to the inadequate master of the production technics. The recrudescence of cattle-rustling leads the Malagasy population to adopt a short cycle animal husbandry. Rabbit-breeding is a real source of income and it makes up for the lack of animal protein in the daily nutrition. The increased prolificacy of doe-rabbits for this kind of breeding is not high. The purpose is to assess the production system of rabbit in the study field. The method is about inquiries and field observations close to 100 peasants in this region. The social, economic and technic data of rabbit-breeding are gathered in the bosom of the farmers. The family agricultural exploitation system characterizes the rabbit production hesitating between politic of supply and that of self-sustenance. Such hesitation in the level of microeconomic is aggravated by the low study level of the farmers and a critical attitude of practices towards the modern norms of cuniculture. The majority of the farmers do not dun rabbit-burrdo and the local of animal husbandry is combined with human's habitation. The rabbits cohabit without any distinction by statute. Generally, green leaves are food distributed to them without taking into consideration by statute. A minority of the farmers give treatment to the sick animals. The performances of this breeding is still so weak because the technical management result is by $50 \%$ inferior to that of the production of a female rabbit in French and the production remains of a dominance of autosustenance yet. Despite the largely traditional practice and a production system on family bases, this activity is profitable in Amoron'i Mania, but with a scanty source of income. The supervision and training of the farmers on the cuniculture technic are primordial, the popularization of the isolated practices of amelioration and the initiatives of solidarity of the "Fihavanana" (kinship) about the common use of buck rabbit producer and green plants.
\end{abstract}

Keywords Cuniculture, Prolificity, Production System, Alimentation, Amoron'i Mania, Solidarity

\section{Introduction}

The lack of animal protein is difficult to control so far subject. Given the increase in theft of oxen, the Malagasy population has adopted other breeding cycle solution courses like rabbit breeding. Rabbit breeding is easy to accomplish and with an interesting productivity [6]. Thanks to the high prolificity and the very short run cycle of production, the does have the potentials of raised production, besides the necessary investment for that kind of animal husbandry is low [6]. For the rabbit farmers, the production acceleration leads to the swiftness of the treasury motion. For the customers, the rabbit's mead has a better nutritional value than ox' and pork's meat [2], [7], [12] usually consummated by the Malagasy population and can make up for the insufficiency of animal protein within the daily nutrition.

In Amoron'i Mania, rabbit-breeding is less developed [16]. That current condition ascertained puts pressure upon the supply of rabbit product. The meat of rabbit and the alive rabbit sale is even rare. That problem of weak rabbit production ascertained brings about the genesis of this study so as to analyze the cause. Many parameters can be considered as factor of underdevelopment of the cuniculture in Amoron'i Mania such as the production system which leads to the product insufficiency in the region studied.

The objective of this study is to get technical and economic data about the current rabbit production and the major problems to the development of this field. That knowledge is useful to apprehend the means which permit the elimination of restraints and to work out appropriate strategies for the development of the sector, to bring about to 
a sustainable production. So as to reach these goals, an assessment of the socio-economic and technical characteristics of rabbit-breeding is necessary in this studied region. The methodological approach adopted consists of the inquiries and observations in the fields by 100 visited animal husbandry. Two hypotheses have been considered in this study: The hesitation at the level of the Agricultural and Family Exploitation (AFE) between the organized system toward the commercial supply and autosubsitence, brings about by a neglect of the farmers in the application of modern technics. As such hesitation in politic micro-economic provokes the weakness of the peasants' income.

\section{Material and Methodology}

The approach methodology adopted consists in investigations and field observations from 100 farmers in four districts of the study area.

\subsection{Material}

100 sheets of investigations have been previously established and used during the collection of field data. The CSPRO version 4.0 software allows you to create an input mask to introduce this information. The XL 2008.6.03 STAT software is used for descriptive statistics.

\subsection{Site Selection}

Near surveys of traders Petite Antananarivo speed markets rabbit sled to the region Amoron'i Mania. Much rabbits for sale in Low speed market are original rabbits Amoron'i Mania, where almost every house hold farmers raising rabbits as a source of fertilizer used for cultivation because of the poor soil in this region. Both arguments have led to choose the region Amoron'i Mania as the research site.

\subsection{Sampling}

Because time constraints, insecurity, materials, information, 100 elevators are surveyed in this region which twenty-five (25) Livestock localities by district. The choice of these family farms of farms visited was done on the basis of their nearest accessible road.

National irrespective of the size of the farm breed of rabbit. This choice also takes into account the safety vis-à-vis investigators zebu thieves "dahalo".The researcher does not consider isolated localities in the red areas.

\subsection{Database Creation}

During the discussion, the researcher realized the data collection by completing the survey form and the pre-established questionnaire in the form of semi-directive questions about the social, technical, economic and breeding issues encountered. During the conversation, the interviewer visits the livestock houses, fulfills the survey sheet.

\subsection{Statistical Data Processing}

The survey forms are stripped and copied to the computer using the CS Pro software version 4.1. The data developed by CS Pro is converted to Excel. This result allows Excel to leave staffing table, as well as percentage curve and graph. This result also obtained by Excel allows for calculations of average, standard deviation, minimum and coefficient of variation using the XL 2008.6.03 STAT software.

\subsection{Data Calculated}

\subsubsection{Calculation of the Expenses of Rabbit Productions}

Total expense $=$ Expense of construction + food Expense

+ Expense on the care and treatment + cost of manpower.

\subsubsection{Calculation of the Returns of Rabbit Production}

- Number of rabbit produces per year = sold rabbit Number + Number of rabbit consummated

- Cost of rabbit produces per year $=$ Number of rabbit produces $\mathrm{x}$ middle Price of rabbit

- Total recipe $=$ Cost of rabbit produces + cost of manure.

\subsubsection{Calculation of the Beneficiary Margin}

The yearly margin $=$ Total recipe - Total expense

\section{Result}

\subsection{Social Features of the Breeder}

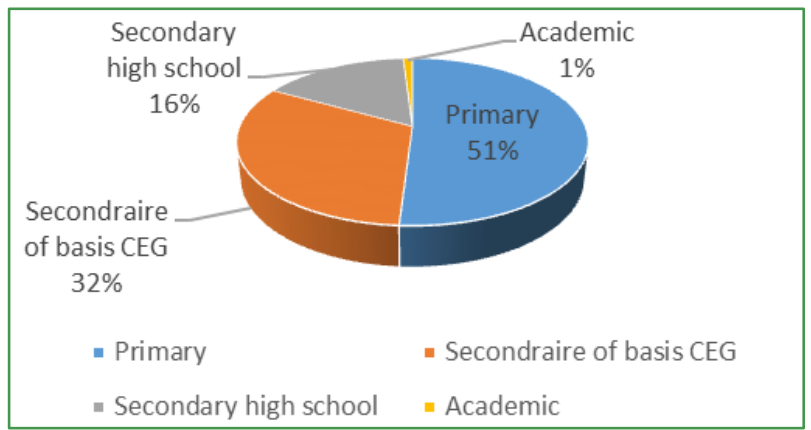

Figure 1. Distribution of the EAF according to the level of survey

According to this figure, the major part of the breeders reinvestigated is level primary $(51 \%)$, then of secondary level of basis (CEG) (32\%). The secondary level of the high school $(16 \%)$ is minority. The academy clever is very rare (1\%). This result shows that the level of most breeder survey is very low. As for the level of survey increases, the number of the breeders decreases. Concerning the rabbit formation as a preliminary, the whole farmers $(100 \%)$ don't have formed about the technic of rabbit production yet.

\subsection{Technical Features of Raising}




\subsubsection{The races of Elevated Rabbit to Amoron'i Mania}

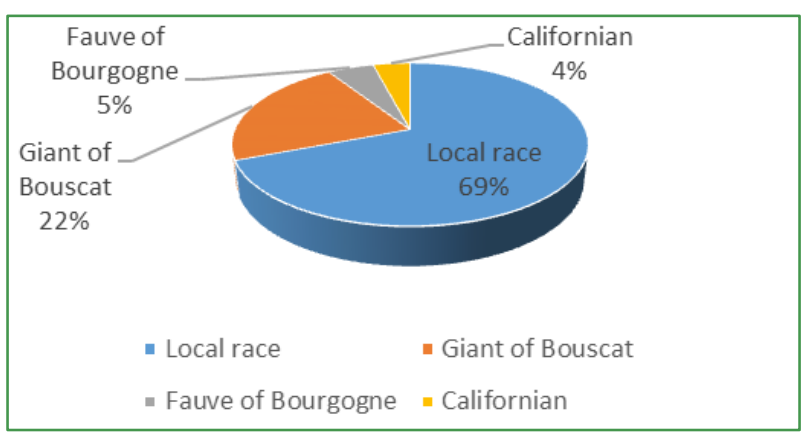

Figure 2. Distribution of EAF according to the elevated race

According to the figure 2, amidst the 4 races existing, the local race dominates in the region with an elevated percentage $(69 \%)$. Then, the race Giant of Bouscat occupies a fairly elevated percentage of $(22 \%)$. The races Fawn of Burgundy and Californian are very rare in this region. Their percentage is respectively $5 \%$ of the Fauve de Bourgogne and $4 \%$ of the Californian race. The inquiries show that $100 \%$ of the visited exploitations did not possess a genealogical registration.

\subsubsection{The house of Rabbit Breeding}

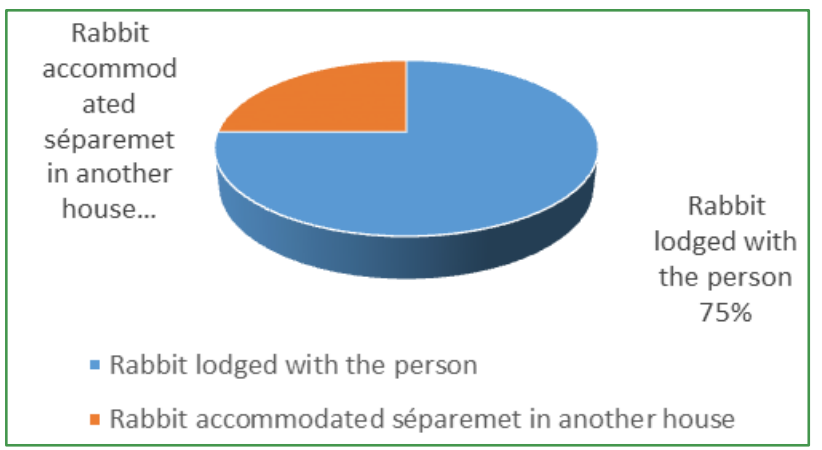

Figure 3. Distribution of the EAF according to the presence of raising house separated of dwelling house

According to the figure 3 and the investigations on land $75 \%$ of rabbit raisings are combined totally with the building of breeder dwelling. In this case some raisings are in the same room with the man or in the same buildings with the man but of different room. Among these breeders investigated, only the $25 \%$ possess one of breeding separated of their dwelling house.

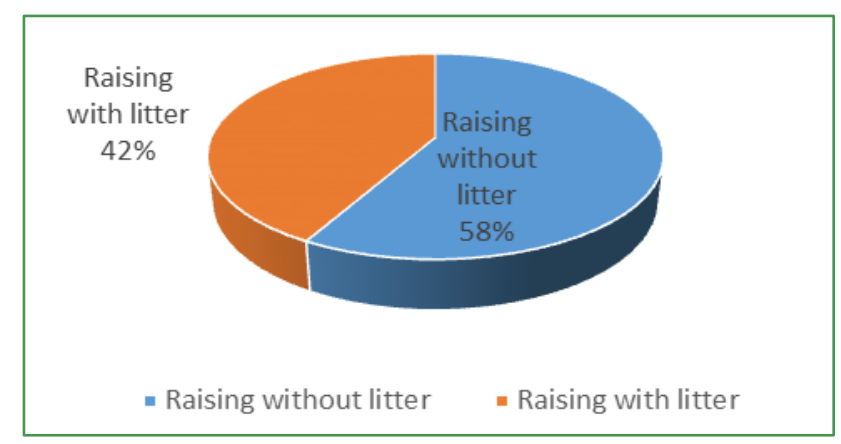

Figure 4. Distribution of raisings according to the use of litter
According to the figure 4, the majority of raisings doesn't use the litter (58\%). Only a minority uses some litters (42\%) but the renewal makes itself two or three times per year.

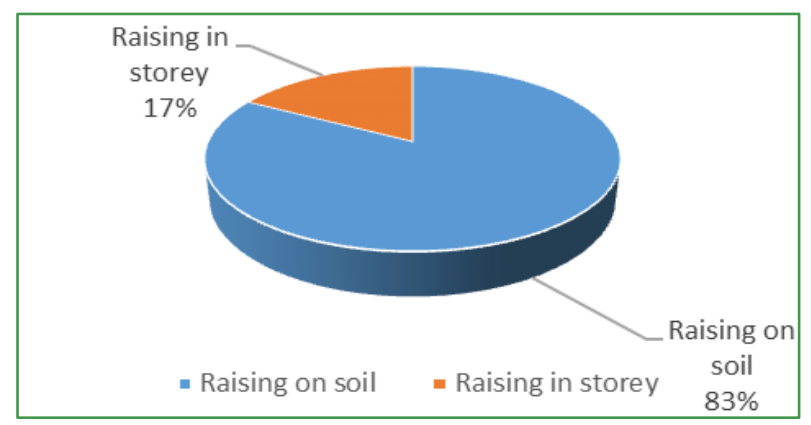

Figure 5. Distribution of the EAF according to the fashion of raising

According to this figure $5,83 \%$ are raisings on soil without use of litter. $17 \%$ are only breeding in floor.

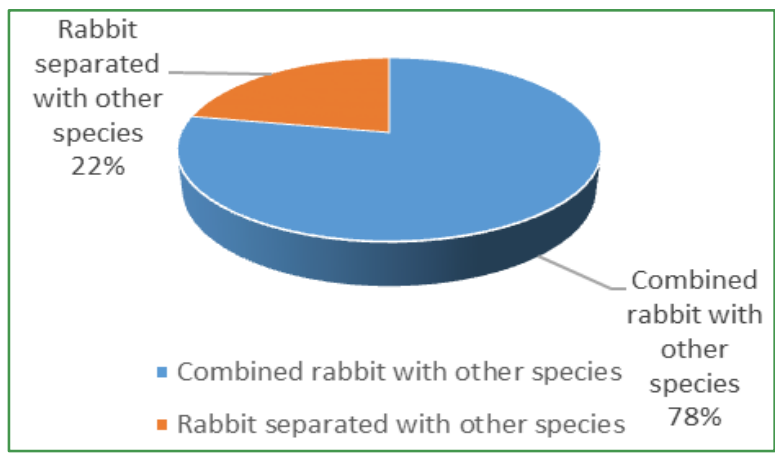

Figure 6. Repartition of the agricultural and family exploitation according to the combination with others species

According to the figure 6, most breeder (78\%) separate the rabbits with other animals who risk killing them. Whereas $22 \%$ some breeder combine their rabbits with other animals (a fowl)

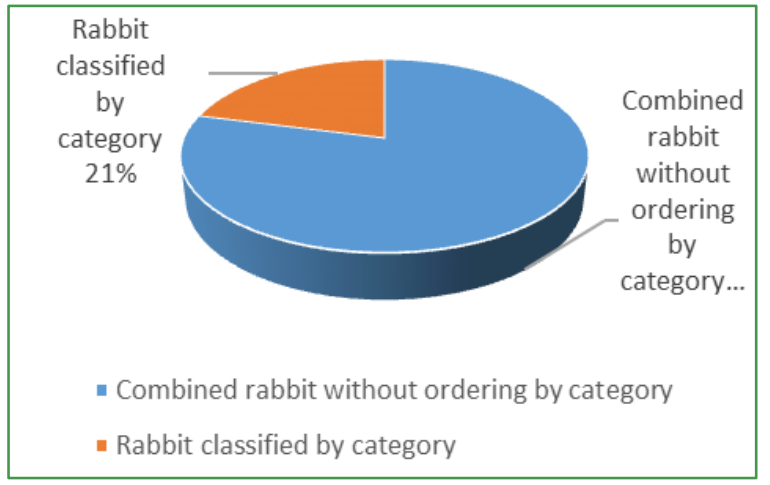

Figure 7. Distribution of the EAF according to the ordering of rabbit by category

According to the figure 7 the majority of breeding is without ordering of rabbit by statute (79\%). That is to say that the elevated rabbits are all compounds in only one room without partitioning and without distinction of sex and category. Only, a minority of breeder follows the norm for 
the ordering of the rabbits by statute $(21 \%)$. In that case, the house of dwelling is partitioned to have several small cages in order to classify the rabbits.

\subsubsection{Food}

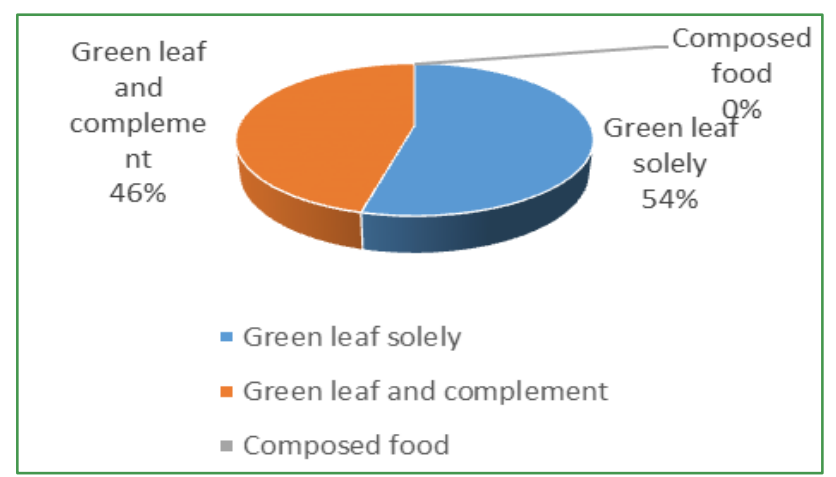

Figure 8. Distribution of the EAF according to the food regime of the rabbits

According to the figure 8 and the investigations on land, the majority of the AFE distributed solely to the green leaf rabbit (54\%). Certain farmers who distribute green leaves and the complement (rice, cassava, sweet potatoes) occupy a second place (46\%). These breeders valorize all human food garbage for feeding the rabbits. The use of provender (composed food) doesn't exist for the population investigated in the region Amoron'i Mania (0\%). The breeder achieves this activity by groping and without objective. Most breeders think that the use of provender is difficult and expensive.

\subsubsection{Health}

According to the figure 9, the majority of the Agricultural Family Exploitation (AFE) underestimates the disease of rabbit (55\%). These breeders note the very frequent death of several rabbits without obvious symptom. $35 \%$ of the breeders affirm that scabies is the more frequent disease at them. $10 \%$ of the breeders noted the coexistence of scabies with the diarrhea that provokes the successive death of rabbits. No breeder signaled the existence of diarrhea only $(0 \%)$.

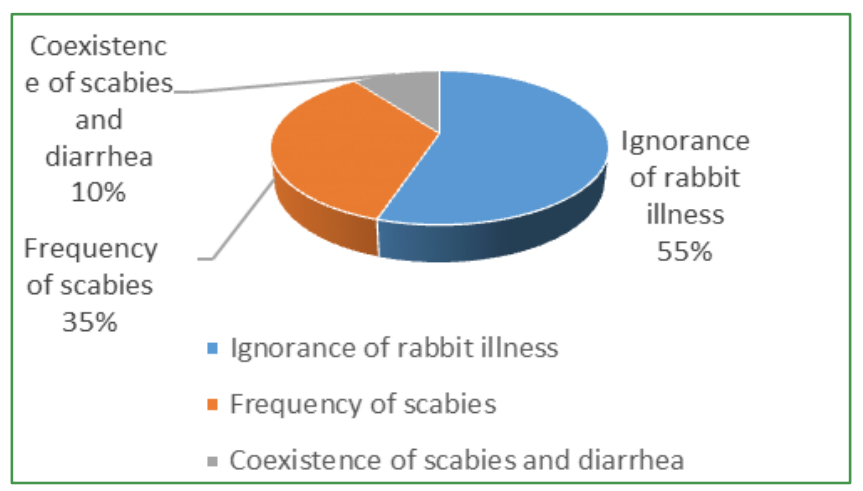

Figure 9. Distribution of the AFE according to the frequency of disease

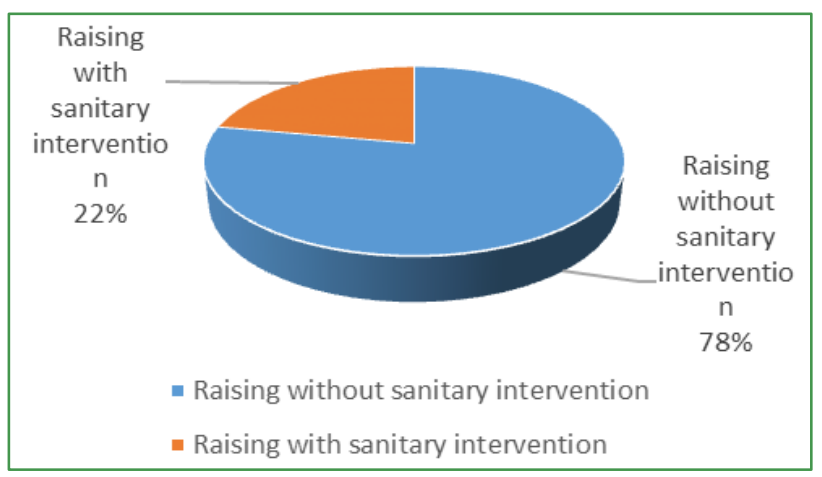

Figure 10. Distribution of the breeder according to the sanitary intervention

According to the figure 10, most exploitation is without sanitary intervention even in case of disease (78\%). A minority of exploitations is with sanitary intervention, killing the parasitical and decontamination of the raising locality $(20 \%)$.

3.2.5 The result of the reproduction and the rabbit production

Table 1. Result of the reproduction and the rabbit production

\begin{tabular}{clc}
\hline Parameters & \multicolumn{1}{c}{ Modality } & Average \\
\hline & $\begin{array}{l}\text { Number of low placing per } \\
\text { female per year }\end{array}$ & $4,5 \pm 0,6$ \\
$\begin{array}{c}\text { Reproduction } \\
\text { parameter }\end{array}$ & $\begin{array}{l}\text { Number of total born per low } \\
\text { placing }\end{array}$ & $5,6 \pm 0,2$ \\
& $\begin{array}{l}\text { Number of alive born per low } \\
\text { placing }\end{array}$ & $5,1 \pm 0,3$ \\
& Rate of mortality of young rabbit & $13,6 \pm 1,5$ \\
\hline \multirow{2}{*}{$\begin{array}{c}\text { Parameter of } \\
\text { production }\end{array}$} & $\begin{array}{l}\text { Age to the sale (month) } \\
\text { Medium weight to the sale }(\mathrm{kg})\end{array}$ & $4 \pm 0,5$ \\
& Density of rabbit $\left(\mathrm{m}^{2}\right)$ & $3,2 \pm 0,8$ \\
\hline
\end{tabular}

The table 1 represents the result of the reproduction and the rabbit production. From this chart, the medium age to the sale of rabbits was supplied by $76 \%$ of the farmers. It was of 4 months (extreme: 3 to 8 months). For the alive weight to the sale, the inquiry pointed out a medium weight of $1,8 \mathrm{~kg}$ (extreme: 1,4 to $3,2 \mathrm{~kg}$ ) for the farmers who supplied an answer. Concerning the number of low placing per female per year, the inquiry pointed out an average of 4,5 low placing per female and per year. The inquiry has brought back a number of total average bore of 5,6 young rabbits by low placing. That study has shown an average of alive born per low placing of 5,1 young rabbit per year.

The result about the number of died per bear allow to calculate the number of died per bear allow to calculate the mortality of rabbit. The rate of mortality between 0 to $20 \%$ had a value very high of the percentage $(68 \%$ of the exploitations). The mortality between 20 to $40 \%$ occupied the $18 \%$ of the exploitations. When the mortality of the young rabbit increases, the effective of the animal husbandry is became more and more weak. A minority of animal husbandry ( $5 \%$ of the exploitations) found a mortality so high of the young rabbit ( 80 to $100 \%$ ). Generally, the average rate of mortality of the young rabbit before weaning was of $13,62 \%$. 
Table 2. Expenses, recipes, and annual beneficiary border of the rabbit production (1 year)

\begin{tabular}{cccccc}
\hline Parameter & Average & Standard deviation & Min & Max & CV (\%) \\
\hline Number of sold rabbit & 9 & 8 & 0 & 50 & 92,51 \\
Number of the consummated/year & 15 & 9 & 0 & 50 & 57,37 \\
Price of rabbit & 5196 & 937 & 3333 & 8000 & 18,03 \\
Cost of the production/year & 92333 & 39330 & 68438 & 240313 & 42,52 \\
Annual recipes of production/year & 186474 & 86242 & 79692 & 475500 & 46,24 \\
Beneficiary border/year & 94141 & 63420 & 11255 & 252546 & 67,36 \\
\hline
\end{tabular}

\subsection{Feature Economic of Raising}

The elements of response of the inquiries enable to put out some parameter of farming economy. The table 2 below shows the number of sold rabbit's prince, expenses, recipes and annual beneficiary border of the rabbit production in the Amoron'i Mania Region.

From this chart, the coefficient of variation was superior to $15 \%$ which signifies that the values were changeable with any exorbitant discards. That means that the studied population has been very heterogeneous. The number of sold rabbit was very variable following the objectives of the farmers and the availability of the alimentary resource. The value is varied from 0 to 50 rabbits sold with an average of $9 \pm 8$ rabbits a year and per animal husbandry. The consummated rabbit was higher than that destined for the sale. The consummation per year varies from 0 to 50 with an average of $15 \pm 9$ rabbits. The rabbit's prince has been very changeable too, following the size of the animal. The price is between 3333 to 8000 Ariary with an average of $5196 \pm 937$ Ariary per rabbit.

The total expenses for the production of rabbit is changed from 68438 to 240313 Ariary per year with an average of 92 $333 \pm 39330$ Ariary. The whole recipes along the year is varied from 79692 to 475500 Ariary with an average of 186 $474 \pm 86242$ Ariary per exploitation.

The beneficiary border changed according to the exploitation's size. In general, the values of that beneficiary border found for all the exploitations were positive. The annual border is varied from 11255 to 252546 Ariary according to the productivity of the workroom with an average of $94141 \pm 62420$ Ariary per exploitation along the year.

\subsection{Constraint of Production}

The problems conjured up by the producers along the investigation are presented in the chart below.

Table 3. Distribution of the animal husbandry according to the constraints of production

\begin{tabular}{cc}
\hline Constraints & Percentage (\%) \\
\hline Genetics resource & 30 \\
Lack of technical knowledge and supervision & 40 \\
Sanitary pressure & 18 \\
Alimentation & 6 \\
Theft & 6 \\
\hline
\end{tabular}

From this table, it's pointed out that $40 \%$ of the problems mentioned in the rabbit-breeding turn around the lack of formation and supervision for the technical management of the cuniculture. The genetics resource problem with the dominance of the local breed occupied a second position among the quoted constraints $(30 \%)$. For certain farmers $(18 \%)$, any diseases none mastered were frequent and the treatments are still represented blurred for them. The alimentary problem is the less evoked by the breeders reason why the percentage is work $(6 \%)$. These last farmers demanded the need of complete nutriment (provender) for rabbit so as to resolve the feed shortage problem during the dry period. The problem of theft and security of animals are evoked by a minority of breeders $(6 \%)$.

\section{Discussion and Recommendation}

\subsection{Discussion}

According to BURGAUD [1], rabbit-breeding figures a strong representation of women in 2005. This feminine majority is married in this study according to the result of investigation done to Amoron'i Mania where the $58 \%$ of the breeder investigations are some women. The raising of rabbit doesn't have need of the man power that exercises other a lot stronger activities, what justifies their relatively weak number in relation to the women. That result is contrary those reported in the past by JAZOUI T. et al. [9] in Marocco. That author found that the masculine breeders are more numerous ( $70,4 \%$ the case).

The totality of the farmers $(100 \%)$ non-formed in the rabbit production technic in that study is still superior to which the result found by JAZOUI T. et al. [9] in Marocco. That author reported $95,84 \%$ of the case non-formed. But, the success of an animal husbandry lays principally on the competency of the farmers [15]. That indicates that in that study, the farmers practice this activity by proceeding tentatively without any technical knowledge. That lack of formation constitutes a handicap in the master of the production technics which are necessary to the success of the rabbit exploitation. Accordingly, this animal husbandry is practiced in a traditional way, and remains of a family type and a secondary activity for of the commercial and modern production. 
The level of survey of the breeder has a major influence on the evolution the development and the production. According to DJAGO and al. [5], a good breeder must be above all an intelligent and untiring worker. He/it must have the scent and a good mind of observation while avoiding the bad habit. He/it can follow the new techniques of intervention and improvement of breeding. In revenge, in Amoron'i Mania the majority of the breeder has a low survey level. This insufficiency of survey level is one of the blockage factors that prevent the curiosity, the research of the improvement techniques and even the discussion with the facilitator and farming technicians. This situation accentuates the bad situation of the rabbit breeding in the Region of Amoron'i Mania handled achieved again in a usually traditional system. Consequently, this is very low survey level pulls up the development of this path in this region and aggravates the hesitation to the level of the agricultural and domestic exploitation agricultural and familial between the politics of market and the one of the auto substance the absence of the breeder in full time influence also on the production of rabbit in this region because this activity becomes secondary. But according to DJAGO and al. [6], the rabbit cultural is a very productive and profitable activity for a good breeder because the fecundity of the female rabbit permits to get an important the youngster bunny number quickly. For example, in good conditions of raising, in climate tropical, a good female rabbit.

According to DJAGO and al. [6], the different race of rabbit distinguishes his herself/itself according to the nature and the color of hair and the format of the animal. But according to the done investigation and the observation on land to Amoron'i Mania, five races are found in the Agricultural Family Exploitation (AFE) visited. Among his/her/it's remarkable races, the race the more exploited is the race locale $(40 \%)$. This local race dominance in the exploitations for has explain itself/themselves by the fact that this survey achieved itself in farming environment where raising is practiced more in a goal of source of engrains and less commercial, what drives the breeder to exploit it the local races. In that case, the manures production is of a primary importance and the meat remain secondary. Besides, the dominance of the autosubsistence devaluates the commercial quality of the product. That mentality can be the origin of the insufficiency of rabbit supply in the market and the weakness of the peasants' income.

$75 \%$ of the breeder investigated not possessed of the houses of raising separated of the dwelling house. For decrease risks it of the animals towards the thieves and the carnivorous predators (dogs, mice, and other animals), they combine the rabbits with the house of dwelling of the breeder. Some breeders exercise this method because of the insufficiency of bottom, material of construction and the exploitable surface for a new construction. This situation explains poverty in the farming world. This choice valorizes the spatial resource already existed instead of spending outraged, this method of combination of the house of raising and human dwelling confirms the situation of the rabbit raising achieved of traditional way and domestic type production in the region of Amoron'i Mania handled.

According to SERRES O. [17], LEBAS F. and al. [13], the slots are necessary in order to isolate the female rabbit reproductive to assure the viability of the youngster rabbit it's time for stake low. In the case of raising to Amoron'i Mania this method is not consider by the majority of the breeder to Amoron'I Mania (79\%). The majority of raisings combined the rabbits in the same a room without baffle or separation of the animals by category $(79 \%)$. That value is inferior to the result of JAZOUI T. et al. [9] in Marocco which was till $87 \%$ of the case. That mode of lodging brings about a strong mortality of the young rabbits between weaning and also a weak number of the produced rabbit each year. The reproduction of the young is difficult to manage and increase the risk of early reproduction. This is entails a strong mortality of the small rabbit before severance and driven a weak number of rabbit produces per year. The reproduction of the young is unverifiable, the baggers to the level of the livestock his/her/its none mastered him there a lack of surveillance of the small, an absence of growth follow-up in size and in number of the elevated individuals. This situation is one of the factors of decrease of the effective that the time of the yield. Nevertheless, that practice justifies the existence of consanguineous farm in that studied region. The consanguinity is a cause of the reduction of stock size from generation to generation but also the strong mortality of rabbits. That mode of housing enlarges the surface allocated for the rabbits which diminish the performance of production. According to COMBES S. et al. [3], the augmentation of the available surface provokes numerous displacements of the rabbit that is one cause of the deterioration of the growing performance and of a stringer mortality, morbidity observed. That idea justifies the slowdown of rabbit growing and augment the age to the sale in that study. In more $22 \%$ of the rabbit raising are combined with other animals (poultry). There are possibility of germ transfer and pathogenic agent then between them. That practice favors equally the mortality of rabbit and brings about the effective's reduction.

According to DJAGO and al. [6], the hutches whose soils provided of a clean wire fencing, constitute a remedy already, because the droppings content the coccids falls on the floor and is not able to therefore more re-contaminate the animals. This model of construction or even the equivalent is not visible in the region of Amoron'I Mania. The majority of the breeder uses soil for the inferior of the press immediately like matter available premiere, easy to construct molder expense. This choice is also motivated by a very low standard of living that doesn't permit to spend a lot of money. Some breeder thinks that soil is most convenient because it facilitates the organic matter obtainment and makes a hole of the female before the stake bottom. The practice of the breeding in soil doesn't consider the hygiene of the rabbit and favor the appearance of coccidiose. That practice mainly in the presence of litter augments the rabbit's mortality until being multiple of 5[4]. The non-adaptation of cage detected in that 
study can also be one of the factors determining the produced rabbit's effective at the origin of bad result of technical management in that region.

According to DJAGO and al. [6], the clean litter is added all 2 on 3 days and that the totality of the litter must be renewed all 7 on 10 days (of 1 times per week at 2 times all 3 sowed born at least). This is not the case in the region of Amoron'I Mania. The totality of raising makes itself on soil, the renewal of litter is disregarded. For the case of rearing to soil cleaning makes itself only during the organic matter evacuation about two or three times per year. What implies the lack of control of tidiness and hygienic during of the realization of the breeding rabbit in this region.

According to LEBAS F. [10], it is necessary to determine the type of raising in order to exercise the food recommendation. It must follow very near the food of rabbits by the choice of the food type intended to the animals according to their age and their type of production; The follow-up of this technology is missing for the raising of rabbit to Amoron'i Mania. The majority of the breeder only distributes the unique green leaf (54\%), and a few minorities reinforcing with of the complements. The distribution of food in disturbed doesn't exist in addition; they distribute foods without consideration of the necessity in quantity and quality according to category of the animals. That practice of green food distribution sole without any respect of the nutritional needs consistent provokes also a bad performance zootechnic. For LEBAS F. [10], the use of all balanced food doesn't allow the breeders to profit of the genetics potential of their animals. The use of balanced food is a mean, key for a better production because it can have multiple influences on the rabbit performance: performance of reproduction, of growth and the reduction of the mortality [10]. That practice of alimentation restarted can so be the origin of the bad technic result in Amoron'I Mania.

One can say that the breeder of rabbit to Amoron'i Mania is again far from being professional. The amelioration of the production is this path. The politics of public establishment centralization (CEG and High school) will be continued to increase the level of farming instruction. The solutions and measures long-term would be studied to solve the problems of insecurity in Madagascar.

According to DJAGO and al. [6], one of the geneses of the mites of agent origins responsible of the itch is the soiled object. According to investigate in Amoron'i Mania, un-respect of the cleanliness and hygiene in the house of breeding is remarkable. This bad habit encourages the evolution of this illness. The bad conception of building and the non-utilization of cage soil either fenced equivalent drives to the humidity of the raising house. In addition, the majority of breeding is again on soil that provokes the retention of the humidity encouraging the spot of the litters, food loss and matter organic.

Following the result of investigation to Amoron'i Mania, 97\% of Agricultural Family Exploitation (AFE) are without treatment of animals and without preventive action. That result is contrary to that of BURGAUD A. [1], in France where the rabbit farming uses quantities of very important antibiotic. This situation explains itself by technician's insufficiency in animal health or breeding to discuss, to note and to solve the facts in the farming world. The breeders are in state of same ignorance of the simple diagnostic of symptom, reason and treatment of illness. This pain treatment and absence of prevention in the majority of breeding are a main reason of bad result of rabbit product in this region investigates.

The technic result reported above is very weak compared with the French production. The average of produced rabbits per year is obtained by the sum of sold rabbits and consummated, give 24 rabbits per year pear exploitation. That number of produced rabbits doesn't reach but the half of a female production per year in France. As for LEBAS F. and al. [11], a female hybrid produces 48 to 50 rabbits of butcher per year. We can say that the average numerical productivity of rabbits of this current study is near to $50 \%$ inferior to that of doses of the French breeding lead by artificial insemination. That result from Amoron'i Mania has a very high discard as that which was reported by XICCATO G. et al. [18], in Vénétie, that reported an average of sold rabbits of 42,8 by female each year. The bad result in this study can be due to the practice of the traditional breeding: non-practice of weaning, non-intervention of the breeder to make the rabbits gush out, consanguineous breeding and the increase of stock mortality too, caused by the lack of technical and sanitary supervision.

The average age to the sale around 120 days (4 months) in Amoron'I mania so as to get a medium weight of $1,8 \mathrm{~kg}$ isn't alike those reported in the past by GUERDER F. [8], in France (72 days), by XICCATO G. and al [18], in Vénétie (83 days). But, it is essential to not that the age and weight alive to the sale of this study is alike those reported by JAZOUI T. and al. [9], in Marocco. The long last of breeding in that study results from a diminution of the growing speed due to the physical activity of the animal after the non-respect of the suitable density during the cage construction, but also caused by the use of the local breed of slow growth. So, the consequence of the traditional practices, the unbalanced alimentation, the cages non-adapted for rabbits can be bound to that bad result of the technical management.

According to MOENS M. [14], in spite of the numeric productivities and a modest relative weight, the raising of rabbit remains profitable: yearly clean margin by reproductive female of $32,000 \mathrm{~F} \mathrm{~b}$ u (France Burundian) superior to the one of the raising agro pastoral the system extensive carping to Bandai. For the domestic raising to Amoron'i Mania this activity is profitable and non-negligible income source. The cost of rabbit production doesn't pass the selling price produces. In this case the difference gives a positive value. The yearly margin is $94141 \pm 63420$ Ariary by exploitation. That shows the results of two or several reproductive females in a farm. This value is minimal in relation to result it of Burundi with well-organized exploitation and professional. This difference resides in the 
lack of capacity of the rabbit breeder but also in the difference of the again domestic and traditional operating system in the studied region. This weakness of the yearly margin is bound to the investment done by the breeder. In this region the investment achieved by the breeder is very weak and same hopeless for some parameters. Of this fact the size of exploitation is small the investments also weak on the construction, the medical and sanitary expenses, zero on the food, hygiene and prophylaxis that the materials of breeding Besides, there is not budget planned for the raising of rabbit. This insufficiency of bottom and investment justifies the quantity reduced the yearly margin by exploitation.

The major constraint of this breeding the most serious is the lack of formation of the breeders on the cuniculture. Every one accepts and recognizes the importance of preliminary formation in animal husbandry. A long the surveys, the majority of producers affirmed that the master of technical knowledge in term of conduct and flock management remain the key of the success of that exploitation. That lack of technical knowledge is also at the origin of genetics resource problem. In that case, the production is not preliminary planned to exploit the characteristics of a breed, even though the conformation of animal diminishes from a generation to another is caused by the consanguineous breeding. Moreover, the absence of breeders association, lack of formation structure and the supervision in almost the whole studied field are prejudicial to the development of the rabbit production. That failure of organization justifies the default of consideration of that field in Madagascar. Accordingly, this activity remains secondary and practiced in a traditional way. The sanitary pressure also occupies a big place in the blocking-up factor. That point is related to the lack of hygiene in the firm. Besides, the failure of sanitary supervision, distribution of medicines, popularization of the technologies are the aggrieving factor of the sanitary pressure. Certain producers affirmed the ignorance of the disease symptoms, the treatments and the necessary prophylaxis. By the absence of technician of supervision and/or veterinary, much exploitation didn't have the sanitary intervention even in case of disease.

The problem evoked by the breeders is all constraints to the development of cunicole production. These constraints allow to search the essential conditions to the success of such exploitation. Those difficulties are generally bound to the behavior or mode of life of the producers, at the supervision of technicians, at the politic of development agreed by the state, the availability of resource in the physical space and the insufficiency of the financial resource.

This study leads not only to search the strategy in order to maximize the production but also to minimize the risks of the job and guarantee the augmentation of incomes. The success of this breeding depends on the willing of the actors, the available means to exclude or a least diminish the constraints to its development. From that idea, some points will be ameliorable for the best future of this field in the studied region.

\subsection{Recommendations}

In order to assure a good management technical result to the best profitability of an exploitation of the breeding rabbit, he/it comes back to the actors intervening notably in the exploitation to clarify if the objective of raising is of the blows rabbit or the production of manure and to provide the corresponding efforts to this choice. The recommendation concerns three levels of intervening party as the practicing breeder, the technicians of raising, and the administrative authorities.

\section{For the Breeder}

The first activity of food concerns the conception of building and accessory of raising and also the environment. This better mentis about the norm while valorizing the raw materials existing to limit the expenses. These improvements of construction permit to respect the hygienic norms, prophylaxes regular and the care and treatment.

The minority breeder will abandon the traditional and domestic production system to the profit of the industrial production system while adopting the technique of race improvement and the introduction of new more effective race. This change of behavior makes itself while increasing the size of exploitation to be more professional and commercial in order to have margin considerable recipient. The breeder winning to respect the food need of the animals by statute and to attend the activity of reproduction and will avoid to the so much that possible the inbreeding.

\section{For the Technicians of Raising and Researcher}

Framing technical - economic of the rabbit breeder is necessary, so possible while organizing the program the raising of rabbit on the parameters zoo techniques and sanitary for an improvement of the incentive and the profitability of raising and the prevention of the illnesses.

\section{For the Administrative Authorities}

They need to come with the creation of the associations of the rabbit breeder (financial support, concession of credit, etc).The formation will be reinforced by specialists in number being sufficient in zoo technician and or veterinary. The programs of genetic improvement are to also promote that the application of the modern technology. The incentive of the researchers will be studied to find new technologies for donated about 40 youngster rabbit per year, either 50 to $60 \mathrm{~kg}$ of meat per year to merchandise. The mentality of the breeder influences on the goal of his/her/its raising and duct to the consideration of the breeding rabbit like a simple pleasure but not a productive activity and a serious income source. The notion of system as collection of element operated unit, interactive manner permanently can contribute to the classification of the peasant breeder choice. In the region studied, the operating system Agricultural and domestic represent a third type in relation to the theoretical distinction between the fashion of subsistence on the one hand and the commercial profit research on the other hand. 


\section{Conclusions}

The survey made in the zone of rabbit production in the Amoron'I Mania Region, Madagascar has enable, from the evaluation of the socio-economic and technical characteristics of breeding, to identify the leading characteristics of breeding, to identify the leading mishaps to the cuniculture's development. From that study, it's pointed out that the cuniculture is generally a secondary activity for women aged of 30 to 50 years at a level of primary study. The modality of practiced animal husbandry confirms the family and traditional characters of this field. In that case, the performances of this breeding is still so weak because the technical management result is by $50 \%$ inferior to that of the production of one female rabbit in French and the production remains of a dominance of autosustenance yet. The non-development of this field in that region is due to the very low level of study of the farmers, aggravated by the lack of formation as a preliminary and the supervision on cuniculture.

Those failures favor the non-master of the suitable technics. The weak level of study induced a mentality far from the commercial production well organized, that confirm the hypothesis stipulating that « the hesitation at the level of Agricultural and Family Exploitation between the organized system towards the commercial supply and the autosustenance, brings about a carelessness of the breeders about the application of modern technics ». Besides, the investment is small or missing to the construction, the alimentation, the care and treatment of the rabbit. In that fact, the expenses of production are weak, that give back an annual beneficiary border positive.

That activity is profitable for the peasants but induce a money resource weak correlatively to small investment effected. That weak resource justifies the second hypothesis formulating that « the hesitation an politic micro-economic provokes the weakness of the peasants' income».

Those performances can still be ameliorated by the use of the means allowing to eliminate at least to alleviate the major constraints that are technical knowledge, the genetics resource, the alimentary resource and the sanitary pressure. It is obvious that if the conditions indispensables for the success of an exploitation are gathered, this rabbit-breeding supply for a short run the possibilities of animal protein growth and augmentation of the producer's incomes. Par consequent, the research of solutions to the evoked problems above enables to reach that objective. From that restitution, the respect of norms, the adoption of new technics and abandon of the traditional method will prioritized by the farmers so as to increase the productivity of this field. Meanwhile that production growth, the technicians will assess the programming of formation session and the popularization of modern technics of the cuniculture, less administrative authorities will study a politic to augment the level of study of the peasants and the master of the security in the rural world. Internal studies should be conducted in order to master the health and the amelioration of rabbits' breed in that region.

\section{REFERENCES}

[1] Burgaud A., 2010. La pathologie digestive du lapin en élevage rationnel. Thèse pour le Doctorat vétérinaire. Ecole National Vétérinaire d'Alfort ; 13-14.

[2] Combes S., 2004. Valeur nutritionnelle de la viande de lapin. INRA Prod. Anim., 2004, 17 (5), 373-383

[3] COMBES S., LEBAS F., 2003. Les modes de logement du lapin en engraissement : influence sur les qualités des carcasses et des viandes. 10ème journées de la Recherche Cunicole, 19-20 novembre 2003. Paris ; 185-200.

[4] Dal Bosco A., Castellini C., Bernardin M., 2000. Productive performance and carcass and meat characteristics of cage or pen-raised rabbits. 7th world Rabbit congress Valencia (spain). 4-7 july. A : 579-584.

[5] Djago A. Y., Kpodekon M., Lebas F., 2012. Méthode et technique d'élevage du lapin. Elevage en milieu tropical. Revalidé le 09 Aout 2012, 69-70.

[6] Djago A.Y., Kpodekon M., Lebas F., 2007. Le guide pratique de l'éleveur de lapins en Afrique de l'Ouest. 2ème édition révisée, Cuniculture éditeur, $71 \mathrm{p}$.

[7] Gigaud V., Combes S., 2007. Les atouts nutritionnels de la viande de lapin : Comparaison avec les autres produits carnés. $12^{\text {ème }}$ journées de la Recherche cunicoles, France; 187-190.

[8] Guerder F., 2001. Gestion technique : résultats annuels de la GTE RENACEB. Cuniculture $28\left(\mathrm{~N}^{\circ} 151\right), 125-131$

[9] Jazoui T., Barkok A., El Maharzi L., Bouzekraoui A., Archa B., 2006. Etude sur les systèmes de production cunicole au Maroc. Cuniculsture Magazine, 33: 99-110.

[10] Lebas F., 2010. Influence de l'alimentation sur les performances des lapins. Séminaire Tunis -9 Décembre 2010, 6 p.

[11] Lebas F., Combes S., 2001. Quel mode d'élevage pour un lapin de qualité ? CRIT Valicentre - Journée technique du 27 Novembre 2001 - Chambray-les-Tours. Toulouse, 1-10.

[12] Lebas F., Marionnet D., Henaf F. R., 1991. La production du lapin. $3^{\text {ème }}$ édition. Paris. 1991, 204 p.

[13] Lebas F., Tudela F., Gidenne T., La domestication du lapin (Oryclolagus cuniculus) s'est faite dans des clapiers. Cuniculture Magazine Volume 37. 2010, 54 - 58.

[14] Moens M., 2008, Document d'orientations stratégiques pour le secteur de l'élevage. Volume 1. Organisation des nations unies pour l'alimentation et l'agriculture. Division du centre d'investissement. FAO. Burundi, 118p

[15] Ndebi G., Kamajou J., Olga J., 2009. Analyse des contraintes au développement de la production porcine au Cameroun. Tropicultura, 27, 2, 70-76.

[16] RASOLOARIMANANA D. D., 2003. Ny Fiompiana bitro. Edition Ambozontany Analamahitsy Antananarivo, 
Madagascar, $72 \mathrm{p}$.

[17] Serres O., 1600 : Le Théâtre de l'agriculture et mesnage des champs, Liev cinquième Chapitre XI La garenne. 1ème édition. Publié à Paris chés Abr. Saingrain rüe St Jacques devant St Benoist, à l'enseigne des deux vipers, 407-419.
[18] Xiccato G., Trocico A., Fragkiadakis M., Majolini D., 2007. Enquête sur les élevages de lapins en Vénétie : Résultats de gestion technique et estimation des rejets azotés. 12ème Journées de la Recherche Cunicole, 27-28 novembre 2007, Le Mans, France, 167-169 